\title{
Prevalence of Centrocestus formosanus Metacercariae in Ornamental Fish from Chiang Mai, Thailand, with Molecular Approach Using ITS2
}

\author{
Atcharaphan Wanlop ${ }^{1}$, Chalobol Wongsawad ${ }^{1,2,3, *}$, Pongphol Prattapong1, Pheravut Wongsawad ${ }^{1,3}$, \\ Thapana Chontananarth ${ }^{4}$, Jong-Yil Chai ${ }^{5,6}$ \\ ${ }^{1}$ Applied Parasitology Research Laboratory, Department of Biology, Faculty of Science, Chiang Mai University, Chiang Mai 50200, Thailand; \\ 2Environmental Science Research Center (ESRC), Chiang Mai University, Chiang Mai 50200, Thailand; '3Science and Technology Research Institute, \\ Chiang Mai University, Chiang Mai 50200, Thailand; ' ${ }^{4}$ epartment of Biology, Faculty of Science, Srinakharinwirot University, Bangkok 10110, \\ Thailand; ${ }^{5}$ Institute of Parasitic Diseases, Korea Association of Health Promotion, Seoul 07649, Korea; ${ }^{6}$ Department of Parasitology and Tropical \\ Medicine, Seoul National University College of Medicine, Seoul 03080, Korea
}

\begin{abstract}
The prevalence of Centrocestus formosanus metacercariae was investigated in ornamental fish purchased from a pet shop in Chiang Mai, Thailand, including Carassius auratus (goldfish), Cyprinus carpio (Koi), Poecilia latipinna (Sailfin Molly), Danio rerio (Zebrafish), and Puntigrus tetrazona (Tiger barb). The parasite species was identified by the morphology of worms as well as by a molecular approach using ITS2. The results showed that 50 (33.3\%) of 150 fish examined were infected with the metacercariae. The highest prevalence was found in C. auratus $(83.3 \%)$, and the highest intensity was noted in C. carpio (70.8 metacercariae/fish). The most important morphological character was the presence of 32-34 circumoral spines on the oral sucker. The phylogenetic studies using the rRNA ITS2 region revealed that all the specimens of $C$. formosanus in this study were grouped together with $C$. formosanus in GenBank database. This is the first report on ornamental fish, C. carpio, P. latipinna, D. rerio, and $P$. tetrazona, taking the role of second intermediate hosts of $C$. formosanus in Thailand. Prevention and control of metacercarial infection in ornamental fish is urgently needed.
\end{abstract}

Key words: Centrocestus formosanus, ornamental fish, Carassius auratus, ITS2, Chiang Mai

Centrocestus formosanus (Nishigori, 1924) (Heterophyidae) was described from Taiwan and now known to distribute widely in Asia [1]. The adult worm lives in the intestine of fisheating birds and mammals [2-4]. Human cases infected with C. formosanus were reported in Lao PDR and Vietnam [4,5]. Pleurolophocercous cercariae are shed from the thiarid snail (Melanoides tuberculata) $[1,6]$. The metacercariae are found on the gill of several freshwater fish species, such as Puntius brevis, Hampala dispar, Puntius gonionotus, Puntius meiacanthus, Cyclocheilichthys armatus, Anabas testudineus, and Henicorhynchus siamensis [7-9]. In addition, the ornamental fish were reported to be infected with $C$. formosanus [2]. The parasite infection causes a problem in fish culture and leads to a reduction of fish production in aquaculture $[1,10]$. The presence of meta-

\footnotetext{
- Received 16 May 2017, revised 20 June 2017, accepted 21 June 2017.

*Corresponding author (wchalobol@gmail.com)

(c) 2017, Korean Society for Parasitology and Tropical Medicine

This is an Open Access article distributed under the terms of the Creative Commons Attribution Non-Commercial License (http://creativecommons.org/licenses/by-nc/4.0) which permits unrestricted non-commercial use, distribution, and reproduction in any medium, provided the original work is properly cited.
}

cercariae on the gills of fish could be one of the reasons for the death of fish [2]. In Thailand, 2 species of Centrocestus, including $C$. formosanus and C. caninus, were reported; however, $C$. caninus is regarded as a synonym of $C$. formosanus [4].

The adult stage of this fluke was found in humans from Chiang Mai and Chiang Rai Provinces, northern Thailand $[11,12]$. The metacercariae were found in several species of freshwater fish [7,13-17]. However, there were few studies on metacercarial infection in ornamental fish species. Thus, the objective of this study was to determine the prevalence and species identification of Centrocestus in ornamental fish purchased from a pet shop in Chiang Mai Province, northern Thailand through morphological and molecular studies.

Total 150 ornamental fish, including 30 Carassius auratus, 30 Cyprinus carpio, 30 Poecilia latipinna, 30 Danio rerio, and 30 Puntigrus tetrazona, were collected from a pet shop in the Mueang District, Chiang Mai Province, northern Thailand during May-June 2016. The metacercariae were investigated on the gill of fish under a stereomicroscope, and then all the mature metacercariae (with X-shape excretory bladder) were collected 
for further studies. Some of the metacercariae were fed to chicks (1-day old), and after 7 days the adult stages were collected from their small intestines. Some other metacercariae were used for molecular studies. The adult stage was used to make a permanent slide according to Boonchot et al. [18]. All specimens were fixed with $4 \%$ formalin, stained with hematoxylin, dehydrated in alcohol series, and finally mounted in permount.

C. formosanus genomes were extracted by Chelex (Fluka, Sigma-Aldrich, St. Louis, Missouri, USA) following Caron et al. [19]. DNA products were amplified with ITS2 region. The reactions were performed in a Thermal Cycler machine (Little Genius, Bioer Technology, Tokyo, Japan). The primer combination; forward 3S (5'-GGT ACC GGT GGA TCA CTC GGC TCG TG-3') and reverse BD2 (5'-TAT GCT TAA ATT CAG CGG GT-
3') were performed in PCR for ITS2 gene. The PCR conditions were as follows: $2 \mathrm{~min}$ initial denaturation at $94^{\circ} \mathrm{C}$, followed by 35 cycles of $1 \mathrm{~min}$ DNA denaturation at $94^{\circ} \mathrm{C}, 1 \mathrm{~min}$ primer annealing at $60^{\circ} \mathrm{C}, 1$ min extension at $72^{\circ} \mathrm{C}$, and $7 \mathrm{~min}$ for final extension at $72^{\circ} \mathrm{C}$. PCR products were tested by gel electrophoresis with DNA Dye NonTox (Applichem, Darmstadt, Germany) stain. After gel electrophoresis, PCR products were purified and sent to sequence analysis. The sequence was analyzed by ClustalW in MEGA software version 6.0 [20]. The sequence of $C$. formosanus was compared and checked by BLAST program on National Center for Biotechnology Information database for species confirmation and gathering of essential sequences for phylogenetic analysis. ITS2 sequences of $C$. formosanus, Centrocestus sp., Haplorchis taichui, Haplorcoides sp., Stellantchasmus falcatus, Paramphistomum epiclitum, Fasciola gi-

Table 1. Prevalence and intensity of infection with Centrocestus formosanus metacercariae in ornamental fish species from Chiang Mai, Thailand

\begin{tabular}{lcccc}
\hline Species of fish & No. of fish examined & No. of fish infected & Prevalence (\%) & Intensity $^{2}$ \\
\hline Carassius auratus (Goldfish) & 30 & 25 & 83.3 & 3.3 \\
Cyprinus carpio (Koi) & 30 & 11 & 36.7 & 70.8 \\
Poecilia latipinna (Sailfin Molly) & 30 & 5 & 16.7 & 1.4 \\
Danio rerio (Zebrafish) & 30 & 6 & 20.0 & 5.2 \\
Puntigrus tetrazona (Tiger barb) & 30 & 3 & 10.0 & 2.0 \\
\hline
\end{tabular}

aMean no. of metacercariae per fish.

Table 2. Measurements (range and mean) of Centrocestus formosanus specimens originating from Carassius auratus $(n=10)$ compared with 2 previous studies

\begin{tabular}{|c|c|c|c|}
\hline $\begin{array}{l}\text { Origin (fish) } \\
\text { Measurements ( } \mu \mathrm{m})\end{array}$ & $\begin{array}{l}\text { Carassius auratus } \\
\text { Present study (Thailand) }\end{array}$ & $\begin{array}{c}\text { Puntius brevis } \\
\text { Han et al. (2008) (Lao PDR) }\end{array}$ & $\begin{array}{c}\text { Carassius auratus } \\
\text { Wongsawad et al. (2017) (Thailand) }\end{array}$ \\
\hline No. of circumoral spines & 34 & $32(32-34)$ & 34 \\
\hline Body width & $176-224$ (204.0) & $155-220$ (192) & $200-290$ (259) \\
\hline Oral sucker length & $48-58(54.4)$ & $45-58(52)$ & $60-80(70.0)$ \\
\hline width & $62-66(64.4)$ & $38-50(43)$ & $52.5-82.5(76.0)$ \\
\hline Prepharynx & $14-34(22.4)$ & - & $17.5-32.5(26.5)$ \\
\hline Pharynx length & $36-46(39.2)$ & 28-34 (32) & $45-57.5(49.5)$ \\
\hline width & $30-40(34.4)$ & $20-30(26)$ & $37.5-50(44.0)$ \\
\hline Esophagus & $26-50(40.8)$ & - & $32.5-62.5(51.5)$ \\
\hline Ventral sucker length & $36-46(42.8)$ & $45-55(48)$ & $52.5-57.5(55.5)$ \\
\hline width & $44-56(51.2)$ & $33-45(35)$ & $55-70(65.5)$ \\
\hline Ovary length & $46-70(56.0)$ & $50-80(60)$ & $62.5-87.5(76.5)$ \\
\hline width & $50-120(81.2)$ & $34-46(42)$ & $65-150(105.5)$ \\
\hline Right Testis length & $60-80(68.8)$ & $45-93(65)$ & $57.5-92.5(76.0)$ \\
\hline width & $94-110(100.4)$ & $24-50(38)$ & $100-137.5(120.5)$ \\
\hline Left Testis length & $48-100(68.0)$ & $55-88(66)$ & $67.5-125(87.0)$ \\
\hline width & $76-100(86.0)$ & $30-63(40)$ & $82.5-125$ (103.5) \\
\hline Egg length & $32-38(34.8)$ & $30-36(34)$ & $40-47.5(43.5)$ \\
\hline width & 20 & $15-19(17)$ & $20-20(20.0)$ \\
\hline
\end{tabular}


gantica, and Heterakis gallinarum from GenBank were aligned with $C$. formosanus from this study. The phylogenetic tree was constructed using the MEGA software version 6.0. The data was analyzed by character analysis (maximum-likelihood) and distance analysis (neighbor-joining) with 1,000 bootstrap values.

Total 50 (33.3\%) of 150 ornamental fish examined were infected with metacercariae of $C$. formosanus. The highest prevalence was found in C. auratus (83.3\%), and the highest intensity of infection was in C. carpio (av. 70.8 metacercariae per fish). The results of other fish are shown in Table 1 . The measurements of adult worms are shown in Table 2. The morphology of $C$. formosanus from 5 ornamental fish was almost similar. The metacercariae were oval shaped, with X-shaped excretory bladder and 32-34 circumoral spines surrounding the oral sucker. The adult flukes were pyriform shaped, and the tegument was covered with scale like spines. All adult worms originating from C. auratus possessed exclusively 34 circumoral spines (Fig. 1A1, A2), whereas those worms originating from other fish were armed with 32 spines arranged in 2 rows (Fig. 1B1, B2). They were both regarded as $C$. formosanus.

The BLAST results of $C$. formosanus originating from $C$. auratus of this study showed 99\% similarity with 5.8S rRNA gene (partial sequence), ITS2 of $C$. formosanus GenBank accession no. KJ630863. The phylogenetic trees were reconstructed based on a maximum-likelihood and neighbor-joining methods with bootstrap values of 1,000 replicates. The results from both methods showed that the topology is similar (Fig. 2) to that of $C$. formosanus originating from C. auratus [25] which

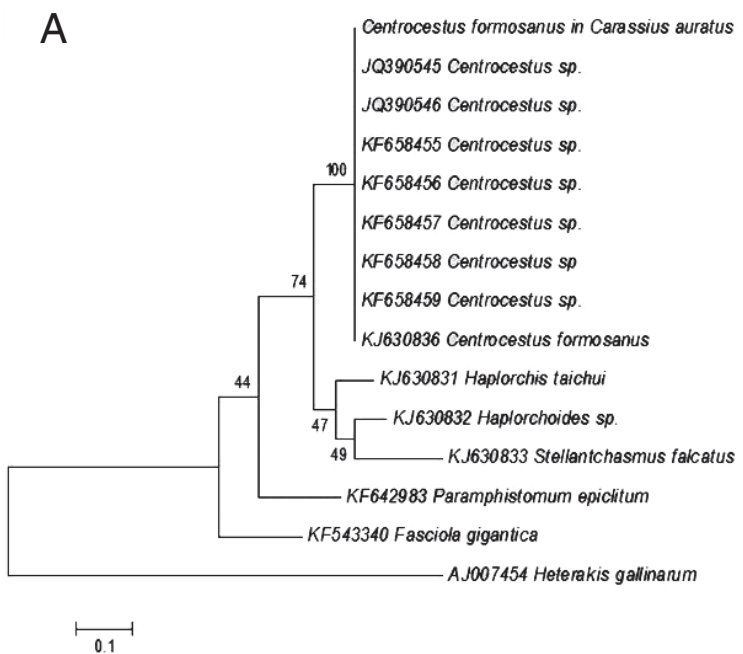

was grouped with Centrocestus sp. and C. formosanus from GenBank with 100\% and 98\% bootstrap values, respectively.
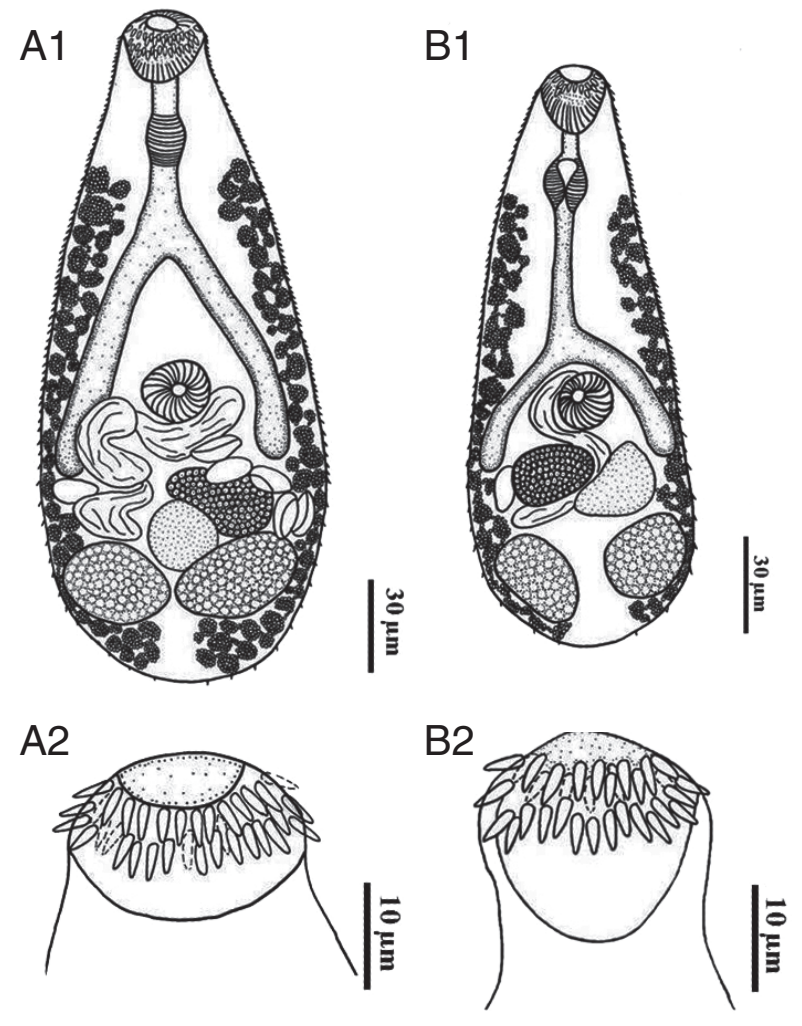

Fig. 1. Line drawing of an adult Centrocestus formosanus originating from $C$. auratus (A1) showing 34 circumoral spines around the oral sucker (A2) and another originating from C. carpio (B1) showing 34 circumoral spines around the oral sucker (B2).

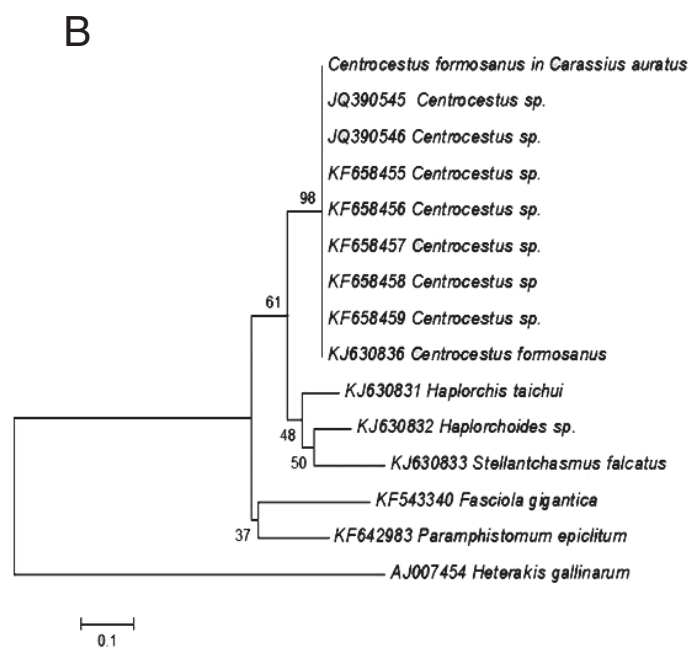

Fig. 2. Phylogenetic trees of C. formosanus originating from C. auratus in Chiang Mai, Thailand. (A) A phylogenetic tree analyzed by maximum-likelihood (ML) method using the MEGA program software version 6.0 with 1,000 bootstrap values. (B) Another tree analyzed by neighbor-joining (NJ) method using the MEGA program software version 6.0 with 1,000 bootstrap values. 
C. formosanus metacercariae were found in ornamental fish from many countries, such as Mexico, Australia, Denmark, and Iran [21-24]. In Thailand, the metacercariae of C. formosanus have been reported in several fish species, such as Macrognathus siamensis, P. gonionotus, P. brevis, Thynnichthys thynnoides, Puntioplites proctozysron, Esomus metallicus, A. testudineus, Parambassis siamensis, and Hampala macrolepidota $[14,25,26]$. However, this fluke is not well known in ornamental fish in Thailand, and in Chiang Mai Province, it has been reported only in C. auratus $[25,27]$. In this study, the metacercariae of $C$. formosanus were found in 5 species of ornamental fish. The results elucidated that ornamental fish can serve as the second intermediate host for $C$. formosanus. In addition, C. formosanus metacercariae were found for the first time in C. carpio, D. rerio, P. latipinna and P. tetrazona in Thailand.

The species confirmation of $C$. formosanus was based on morphological and molecular methods. The unique character of $C$. formosanus is the number of circumoral spines around the oral sucker. They commonly have 32 circumoral spines arranged in 2 rows around the oral sucker $[1,4,8,18,24,28]$, whereas Centrocestus armatus has 42-44 circumoral spines $[3,29,30]$. In the present study, there were 32 circumoral spines in worms originating from 4 fish species (C. carpio, P. latipinna, D. rerio, and $P$. tetrazona) which agreed to previous studies $[1,2,24,28]$. The worms originating from $C$. auratus fish had exclusively 34 circumoral spines which also resembled previous studies [8,21]. Thus, our specimens of 2 different origins were both considered morphologically to be $C$. formosanus. Molecular studies of our specimens using ITS2 by maximumlikelihood and neighbor-joining methods revealed a high relationship with C. formosanus from GenBank. They were separated from other heterophyid flukes and also from P. epiclitum, F. gigantica, and H. gallinarum (out group). The results of morphological and molecular studies were accorded.

This is the first report of $C$. formosanus metacercariae in $C$. carpio, P. latipinna, D. rerio, and P. tetrazona ornamental fish. The phylogenetic trees showed high relationships of our specimens with C. formosanus from GenBank database. Infection of these fish with $C$. formosanus metacercariae should be prevented and controlled. It can also help to reduce the motility rate of fish before export or sell to customers.

\section{ACKNOWLEDGMENTS}

We would like to thank Environmental Science Research
Center (ESRC), Chiang Mai University, Chiang Mai, Thailand. Special thanks to the staff of the Applied Parasitology Research Laboratory, Department of Biology, Faculty of Science, and Chiang Mai University for the facility supported. We are also thankful to the Science and Technology Research Institute, Chiang Mai University for financial support.

\section{CONFLICT OF INTEREST}

We have no conflict of interest related to this study.

\section{REFERENCES}

1. Scholz T, Salgado-Maldonado G. The introduction and dispersal of Centrocestus formosanus (Nishigori, 1924) (Digenea: Heterophyidae) in Mexico: a review. Am Midl Nat 2000; 143: 185-200.

2. Gjurčević E, Petrinec Z, Kozariž Z, Kužir S, Gjurčević KV, Vučemilo M, Džaja P. Metacercariae of Centrocestus formosanus in goldfish (Carassius auratus L.) imported into Croatia. Helminthologia 2007; 4: 214-216.

3. Kimura D, Paller VG, Uga S. Development of Centrocestus armatus in different final hosts. Vet Parasitol 2007; 146: 367-371.

4. Chai JY, Sohn WM, Yong TS, Eom KS, Min DY, Lee MY, Lim H, Insisiengmay B, Phommasack B, Rim HJ. Centrocestus formosanus (Heterophyidae): human infections and the infection source in Lao PDR. J Parasitol 2013; 99: 531-536.

5. De NV, Le TH. Human infections of fish-borne trematodes in Vietnam: prevalence and molecular specific identification at an endemic commune in Nam Dinh Province. Exp Parasitol 2011; 129: 355-361.

6. Pinto HA, de Melo AL. Melanoides tuberculata (Mollusca: Thiaridae) as an intermediate host of Centrocestus formosanus (Trematoda: Heterophyidae) in Brazil. Rev Inst Med Trop São Paulo 2010; 52: 207-210.

7. Srisawangwong T, Sithithaworn P, Tesana S. Metacercariae isolated from cyprinoid fish in Khon Kaen district by digestion technique. Southeast Asian J Trop Med Public Health 1997; 28: 224226.

8. Han ET, Shin EH, Phommakorn S, Sengvilaykham B, Kim JL, Rim HJ, Chai JY. Centrocestus formosanus (Digenea: Heterophyidae) encysted in the freshwater fish, Puntius brevis, from Lao PDR. Korean J Parasitol 2008; 46: 49-53.

9. Eom KS, Park HS, Lee D, Sohn WM, Yong, TS, Chai JY, Min DY, Rim HJ, Insisiengmay B, Phommasack B. Infection status of zoonotic trematode metacercariae in fishes from Vientiane $\mathrm{Mu}-$ nicipality and Champasak Province in Lao PDR. Korean J Parasitol 2015; 53: 447-453.

10. Paller VGV, Uga S. Attachment and penetration of Centrocestus armatus (Digenea: Heterophyidae) cercariae to gills of secondary intermediate fish hosts. J Parasitol 2008; 93: 578-583.

11. Radomyos B, Wongsaroj T, Wilairatana P, Radomyos P, Prae- 
vanich R, Meesomboon V, Jongsuksuntikul P. Opisthorchiasis and intestinal fluke infections in northern Thailand. Southeast Asian J Trop Med Public Health 1998; 29: 123-127.

12. Waikagul J, Wongsaroj T, Radomyos P, Meesomboon V, Praewanich R, Jongsuksuntikul P. Human infection of Centrocestus caninus in Thailand. Southeast Asian J Trop Med Public Health 1997; 28: 831-835.

13. Waikagul J. Opisthorchis viverrini metacercaria in Thai freshwater fish. Southeast Asian J Trop Med Public Health 1998; 29: 324326.

14. Wongsawad C, Rojtinnakorn J, Wongsawad P, Rojanapaibul A, Marayong T, Suwattanacoupt S, Sirikanchana P, Sey O, Jadhav BV. Helminths of vertebrates in Mae Sa Stream, Chiang Mai, Thailand. Southeast Asian J Trop Med Public Health 2004; 35: 140-146.

15. Saenphet S, Wongsawad C, Saenphet K, Rojanapaibul A, Vanittanakom P, Chai JY. The occurrence of heterophyid metacercariae in cyprinoid fish in Chiang Mai province. Southeast Asian J Trop Med Public Health 2008; 39: 56-61.

16. Wongsawad C, Wongsawad P, Anuntalabhochai S, Chai JY, Sukontason K. Occurrence and molecular identification of liver and minute intestinal flukes metacercariae in freshwater fish from Fang-Mae Ai Agricultural Basin, Chiang Mai province, Thailand. Asian Biomed 2013; 7: 97-104.

17. Krailas D, Veeravechsukij N, Chuanprasit C, Boonmekam D, Namchote S. Prevalence of fish-borne trematodes of the family Heterophyidae at Pasak Cholasid Reservoir, Thailand. Acta Trop 2016; 156: 79-86.

18. Boonchot K, Wongsawad C. A survey of helminthes in cyprinoid fish from the Mae Ngad Somboonchon reservoir, Chiang Mai Province, Thailand. Southeast Asian J Trop Med Public Health 2005; 36: 103-107.

19. Caron Y, Righib S, Lempereura L, Saegermanc C, Lossona B. An optimized DNA extraction and multiplex PCR for the detection of Fasciola sp. in lymnaeid snails. Vet Parasitol 2011; 178: 93-99.

20. Tamaru K, Stecher G, Peterson D, Filipski A, Kumar S. Mega6: molecular evolutionary genetics analysis version 6.0. Mol Biol
Evol 2013; 30: 2725-2729.

21. Ortega C, Fajardo R, Enríquez R. Trematode Centrocestus formosanus infection and distribution in ornamental fishes in Mexico. J Aquat Anim Health 2009; 21: 18-22.

22. Evans BB, Lester RJG. Parasites of ornamental fish imported into Australia. Bull Eur Ass Fish Pathol 2001; 21: 51-55.

23. Mehrdana F, Jensen HM, Kania PW, Buchmann K. Import of exotic and zoonotic trematodes (Heterophyidae: Centrocestus sp.) in Xiphophorus malculatus: implications for ornamental fish import control in Europe. Acta Parasitol 2014; 59: 276-283.

24. Mood SM, Ebrahimzadeh Mousavi HA, Mokhayer B, Ahmadi M, Soltani M, Sharifpour I. Centrocestus formosanus metacercarial infection of four ornamental fish species imported into Iran. Bull Eur Ass Fish Pathol 2010; 30: 146-149.

25. Wongsawad C, Wongsawad P, Sukontason K, Maneepitaksanti W, Nantarat N. Molecular phylogenetics of Centrocestus formosanus (Digenea: Heterophyidae) originated from freshwater fish from Chiang Mai Province, Thailand. Korean J Parasitol 2017; 55: 3137.

26. Sukontason K, Piangjai S, muangyimpong Y, Sukontason K, Methanitikorn R, Chaithong U. Prevalence of trematode metacercariae in cyprinoid fish of Ban Pao District, Chiang Mai province, northern Thailand. Southeast Asian J Trop Med Public Health 1999; 30: 365-370.

27. Saenphet S, Wongsawad C, Saenphet K, Chai JY. Mucosal mast cell responses in rats (Rattus norvegicus) experimentally infected with Centrocestus caninus. Southeast Asian J Trop Med Public Health 2006; 37: 446-451.

28. Mati LVT, Pinto HA, Melo Al. Experimental infection of Swiss and AKR/J mice with Centrocestus formosanus (Trematoda: Heterophyidae). Rev Inst Med Trop Sao Paulo 2013; 55: 13-36.

29. Hong SJ, Seo BS, Lee SH, Chai JY. A human case of Centrocestus armatus infection in Korea. Korean J Parasitol 1988; 26: 55-60.

30. Kimura D, Uga S. Epidemiological study on Centrocestus armatus metacercariae in the Chikusa River, Hyogo Prefecture, Japan. Trop Med Health 2005; 33: 7-11. 
